compared with men who got jobs; the unemployed men consulted general practitioners $57 \%$ more often about $13 \%$ more illnesses, were referred to hospital outpatient departments $63 \%$ more often, and visited hospital twice as often. ${ }^{13}$ These results fit with data from the general household survey showing that men seeking work consult general practitioners $80 \%$ more than those in employment, and those who have been out of work for five years or more consult even more often. ${ }^{1+}$

How should health workers respond to this hardening evidence on the harm of unemployment? They must place it before politicians because the appalling human cost of unemployment must not be forgotten in the economic discussions that Worswick's study shows to be less certain than some monetarist economists might pretend. ${ }^{2}$ Training and temporary employment are crucially important, and the evidence is that the government's employment training scheme is not working well: more than half of those completing the scheme are unemployed three months later. ${ }^{15}$ Social security payments should be improved because poverty is one of the main mediators of the damage caused to health by unemployment. Doctors need to be sensitive in their consultations with the unemployed and encourage independence rather than dependence on prescription drugs. Fineman suggests that this may be done in a book published last year. ${ }^{16}$
Finally, it may be that the contracts of the new health service could provide mechanisms for responding to the health problems of the unemployed.

Executive editor,

RICHARD SMITH

$B M \mathcal{F}$

Galbraith JK. Owning up to the recession. Harper's 1991:March:21-5.

2 Worswick GDN. Lnemployment: a problem of policy. Cambridge: Cambridge University Press, 1991.

3 Moser KA, Fox AJ, Jones DR, Goldblatt PO. Unemployment and mortality: further evidence from the OPCS longitudinal study 1971-81. Lancet 1986;i:365-6.

4 Moser KA, Goldblatt PO, Fox AJ, Jones DR. Unemployment and mortality: comparison of the 1971 and 1981 longitudinal study census samples. $B M J$ 1987;294:86-90.

5 Costa G, Segman N. Unemployment and mortality. BMF 1987;294:1550-1.

6 Iversen $\mathrm{L}$, Andersen $\mathrm{O}$, Andersen $\mathrm{PK}$, Christoffersen $\mathrm{K}$, Keiding $\mathrm{N}$. Unemployment and mortality in Denmark, 1970-80. BMF 1987;295:878-84.

Martikainen PT. Unemployment and mortality among Finnish men, 1981-5. BMf 1990;301:407 11.

Mattiasson I, Lindgarde F, Nilsson JA, Theorell T. Threat of unemployment and cardiovascular risk factors: longitudinal study of quality of sleep and serum cholesterol concentrations in men threatened with redundancy. $B M \mathcal{F}$ 1990;301:461-6.

9 Warr PB. Work, unemployment, and mental health. Oxford: Clarendon Press, 1987.

10 Eales MJ. Depression and anxiety in unemploved men. Psychol Med 1988;18:935-45.

11 Beale N, Nethercott S. Job loss and family morbidity: a study of factory closure. $7 R$ Coll (jen Pract $1985: 280: 510-4$

12 Beale N, Nethercott S. The nature of unemployment morbidity. 2. Description. $9 R$ Coll Gen Pract 1988:38:200-2.

13 Beale $\mathrm{N}, \mathrm{Nethercott} \mathrm{S}$. The health of industrial employees four years after compulsory redundancy. IR Coll Gen Pract 1987;38:390-4.

14 Yuen P, Balarajan R. Unemployment and patterns of consultation with the general practitioner. BMF 1989;298:1212-4.

15 Anonymous. ET leazers survey. Working brief. London: Unemployment Unit, 1991:4-5.

16 Fineman S. Supporting the jobless. London: Tavistock, 1990.

\title{
Corticosteroids in bacterial meningitis
}

\author{
Not yet justified for all patients
}

Death rates from bacterial meningitis have remained largely unchanged despite a bewildering portfolio of potent antibiotics. Mortality from Haemophilus influenzae, meningococcal, and pneumococcal meningitis is about $5 \%, 9 \%$, and $20 \%$ respectively. ' The picture is even more gloomy for neonatal Gram negative bacillary meningitis, in which almost half of those infected die $^{2}$ and non-fatal sequelae affect 10$20 \%$ of the survivors. ${ }^{3}$ The early complications include relapse of infection, hydrocephalus, subdural effusion, brain abscess, and cranial neuropathies. Long term complications such as epilepsy, psychomotor retardation, and, in particular, poor hearing may show themselves only at school age. ${ }^{+}$

Much has been learnt about the pathophysiology of bacterial meningitis from experimental injections in rodents and rabbits. Speaking immunologically, the cerebrospinal fluid is a deprived environment, deficient in phagocytic cells, complement, and immunoglobulins. ${ }^{5}$ The cellular response to infection includes evidence of altered polymorphonuclear cell function and impaired phagocytosis. ${ }^{6}$ The rise in hydrostatic pressure in the cerebrospinal fluid, an inflammatory vasculitis, and the accompanying cerebral oedema act together to impair the blood supply to sensitive nerve cells, especially within learning centres such as the hippocampus. ${ }^{7}$ Neuronal function is further compromised by the fall in glucose in the cerebrospinal fluid which accompanies the change to anaerobic glycolysis and lactate accumulation. ${ }^{8}$

For many years great emphasis was placed on microbial virulence to explain these events. The spotlight is now firmly on the host response to infection, however, and in particular an increasing array of signal molecules. Identification of cytokines such as tumour necrosis factor (cachectin), interleukins (especially interleukin 1 and interleukin 6), interferons, prostaglandins $\left(\mathrm{PGE}_{2}\right.$ and $\left.\mathrm{PGI}_{2}\right)$, and platelet activating factor have increased our understanding of the complex pathophysiology (C Cabellos et al, interscience congress on antimicrobial agents and chemotherapy, Atlanta, Georgia, 1990).9.11

Microbial products play a critical part in triggering these cytokine cascades. These include pneumococcal peptidoglycan and teichoic acid, cell wall oligosaccharide from $H$ influenzae, and cell wall lipid A (endotoxin) in Gram negative bacteria. ${ }^{12}$ Indeed, much of the inflammatory response can be provoked by administration of endotoxin, and in experimental meningitis in animals this leads to a vigorous increase of tumor necrosis factor, lactate, and IL-1 in the cerebrospinal fluid. ${ }^{13}$ Release of endotoxin and IL-1 $\beta$ has also been shown to occur in humans being treated for meningitis and is in part brought about by lysis of microbial cells in response to antibiotics. ${ }^{1}$

In pharmacological doses adrenal corticosteroids down regulate many components of the inflammatory response and also lower cerebrospinal fluid hydrostatic pressure. ${ }^{15}$ Despite their chequered history in the treatment of serious sepsis corticosteroids are under investigation once again in the treatment of acute, non-tuberculous bacterial meningitis. This is in spite of much published work showing no firm evidence of an improved outcome: a recent meta-analysis of published randomised concurrently controlled studies of steroids in the treatment of meningitis failed to support their use in bacterial meningitis in either children or adults. ${ }^{16}$ This result may not, however, have been unexpected owing to the variation in choice of steroid, dosage regimen, duration, and timing of treatment. Nevertheless, while recent progress in understanding the pathophysiology of meningitis and the role of cytokine mediators has stimulated the investigation of a range of inhibitors of these signal molecules-such as 
indomethacin, oxindanac, ibuprofen, and oxpentifylline ${ }^{12} 1718$ - it has also led to a reassessment of the role of corticosteroids.

Experimental studies in animals have clearly shown that the timing of administration of antibiotics and steroids is critical; corticosteroids must be given simultaneously or shortly before antibiotics if maximum benefit - as measured by a reduction in cerebrospinal fluid lactate, tumor necrosis factor, and interleukin $1-$ is to be achieved. ${ }^{19}$ This has stimulated several clinical trials in which various antibiotic regimens have been administered to patients with a variety of bacterial meningeal infections, with or without the addition of corticosteroids.

Two important studies have been published from the United States and Egypt. ${ }^{2021}$ The American study compared prospectively cefuroxime and ceftriaxone with or without dexamethasone $(0.15 \mathrm{mg} / \mathrm{kg}$ six hourly for four days) in the treatment of bacterial meningitis in infants and children. ${ }^{20}$ Those receiving dexamethasone achieved higher cerebrospinal fluid concentrations of glucose and lower concentrations of lactate and protein and lower leucocyte counts at 24 hours, and they also became afebrile sooner. There was no effect, however, on the rate of sterilisation of the cerebrospinal fluid. The incidence of subdural effusions, seizures, and neurological abnormalities at discharge was substantially reduced. In particular, the moderate to severe bilateral hearing loss in children with $H$ influenzae meningitis treated with cefuroxime was reduced by dexamethasone-but only to a level previously reported in patients treated with non-steroid drugs. ${ }^{12}$ No benefit from the steroid was seen in those treated with ceftriaxone. Cefuroxime cannot be considered comparable in efficacy to ceftriaxone because treatment failures and slow sterilisation of the cerebrospinal fluid are well recognised and probably related to the lower concentrations achieved in the cerebrospinal fluid. Only one death occurred among the 200 patients recruited to this study - a lower mortality than that usually associated with bacterial meningitis; this suggests the possibility of patient selection. In those treated with dexamethasone two had gastrointestinal haemorrhages requiring blood transfusion and a further two patients had occult blood in the stools.

In the study from Egypt 429 patients (which included children and adults) with bacterial meningitis were randomised to receive ampicillin or chloramphenicol, with or without dexamethasone (three days treatment of $8 \mathrm{mg} 12$ hourly for those under 12 years of age and $12 \mathrm{mg} 12$ hourly for those over 12 years). ${ }^{21}$ Again, a variety of bacterial meningeal infections were treated. Mortality was reduced only in those patients suffering from pneumococcal meningitis and receiving dexamethasone (7/52 v 22/54). Corticosteroids also protected against hearing loss in this group of patients. In contrast to the American study there was no difference in the inflammatory response in the cerebrospinal fluid at 24-36 hours as evidenced by concentrations of glucose and protein and the leucocyte count.

These studies have influenced the use of dexamethasone as supplementary treatment in bacterial meningitis of childhood in the United States. A poll of paediatric specialists in infectious disease found nearly four fifths in favour of the use of dexamethasone, either occasionally or universally. ${ }^{22}$ Although the evidence to date is encouraging, we do not believe it justifies routine use in all patients with pyogenic meningitis. The total number of patients randomised to receive corticosteroids in these studies has been limited and only subpopulations have shown benefit. The regimen is not without risks of side effects, further supporting the need for more information to assess the risks to benefits. Dexamethasone may reasonably be given to patients who are severely ill and in particular those comatose with $H$ influenzae infection. A presumptive microbiological diagnosis of this infection can, however, be based only on Gram stain examination of the cerebrospinal fluid - and thus can prove difficult. Another factor that should be taken into account in interpreting these trials is that release of endotoxin varies according to antibiotic challenge, $\beta$ lactams (as used in the American study) being more efficient than agents such as chloramphenicol. ${ }^{23}$ Thus, important questions remain concerning the place of corticosteroids in the treatment of bacterial meningitis. These require clarification by further carefully conducted clinical trials in homogenous populations. In the meantime further exciting advances can be expected as new anti-inflammatory agents are pitched against this most challenging infectious disease.

ROGER G FINCH

Consultant and Senior lecturer in Microbial Diseases COSTAS MANDRAGOS

Honorary Clinical Research Fellow Department of Microbial Diseases and University of Nottingham,

City Hospital, Nottingham NG5 IPB

I Finch R. Bacterial meningitis. Prescribers fournal 1989;29 (1):2-10.

McCracken (GH Jr, Mize SG, Threlkeld N. Intraventricular gentamicin therapy in Gram-negative bacillary meningitis of infancy. Report of the second Neonatal Meningitis Cooperative Study Group. Lancet 1980;i:787-91.

$3 \mathrm{McCracken} \mathrm{GH} \mathrm{Jr}$. Management of bacterial meningitis in infants and children: current status and future prospects. Am F Med 1984;76:215-23

4 Dodge PR, Davis H, Feigin RD, et al. Prospective evaluation of hearing impairment as a sequela of acute bacterial meningitis. $N$ Engl f Med 1984;311:869-74.

Whitby $M$, Finch R. Bacterial meningitis: rational selection and use of antibacterial drugs. Drugs 986;31:266-78.

6 Tauber MG, Borschberg U, Sande MA. Influence of granulocytes on brain edema, intracranial pressure, and cerebrospinal fluid concentrations of lactate and protein in experimental meningitis. F Infect Dis 1988; 157:456-64.

7 Simon RP. Role of endogenous excitatory amino acid neurotransmitters in the pathogenesis and evolution of acute brain injury. Pediatr Infect Dis $\mathcal{F}$ 1989:8:913-5.

8 Tureen J. Cerebral blood flow and metabolism in experimental meningitis. Pedialr Infect Dis $\mathcal{f}$ 1989;8:917-8.

9 Waage A, Halstensen A, Espevik T. Association between tumour necrosis factor in serum and fatal outcome in patients with meningococcal disease. Lancet 1987; i:355-7.

10 Sande MA, Tauber MG, Scheld $M$, McCracken GH Jr. Pathophysiology of bacterial meningitis: summary of the workshop. Pediatr Infect Dis $\mathcal{F}$ 1989;8:929-33.

11 Mustafa MM, Ramilo O, Sae $z$-Llorens X, Mertsola J, Magness RR, McCracken GH Jr. Prostaglandins $\mathrm{E}_{2}$ and $\mathrm{I}_{2}$, interleukin I-beta, and tumor necrosis factor in cerebrospinal fluid of infants and children with bacterial meningitis. Pediatr Infect Dis $\mathcal{f}$ 1989;8:921-33.

12 Niemoller UM, Tauber MG. Brain edema and increased intracranial pressure in the pathophysiology of bacterial meningitis. Eur 7 Clin Microbiol Infect Dis 1989;8:109-17.

13 Mustafa MM, Ramilo O, Olsen KD, et al. Tumor necrosis factor in mediating experimental Hacmophilus influenzae type b meningitis. F Clin Invest 1989;84:1253-9.

14 Mustafa MM. Mertsola J, Ramilo O, Saez-Llorens X, Risser RC, McCracken GH Jr. Increased endotoxin and interleukin l-beta concentrations in cerebrospinal fluid of infants with coliform meningitis and ventriculitis associated with intraventricular gentamicin therapy. I Infect Dis meningitis and
$1989 ; 160: 891-5$

15 Tauber MG, Khavam-Bashi H, Sande MA. Effects of ampicillin and corticosteroids on brain water content, cerebrospinal fluid pressure, and cerebrospinal fluid lactate levels in experimental pneumococcal meningitis. F Infect Dis 1985; 151:528-34.

16 Havens PL, Wendelberger KJ. Hoffman GM, Lee MB, Chusid MJ. Corticosteroids as adjunctive therapy in bacterial meningitis. Am F Dis Child 1989;143:1051-5.

17 Kadurugamuwa JL, Hengstler B, Zak O. Cerebrospinal fluid protein profile in experimental pneumococcal meningitis and its alteration by ampicillin and anti-inflammatory agents. $\mathcal{F}$ Infect Dis 1989;159:26-34

18 Saez-Llorens X, Ramilo O, Mustafa MM, Mertsola J, Hansen EJ, McCracken GH. Modulation of meningeal inflammation by treatment with pentoxifylline. Pediatr Infect Dis $\mathcal{f}$ 1989;8:922-3.

19 Tauber MG, Sande MA. Dexamethasone in bacterial meningitis: increasing evidence for a beneficial effect. Pedialr Infect Dis f 1989;8:842-4.

20 Lebel MH, Freii BJ, Syrogiannopoulos GA, et al. Dexamethasone therapy for bacterial meningitis. N Engl F Med 1988; 15:964-71.

21 Girgis NI, Farid $Z$, Mikhail IA, et al. Dexamethasone treatment for bacterial meningitis in children (irgis NI, Farid Z, Mikhail IA, et al. Dexametha
and adults. Pediatr Infect Dis $\mathcal{f}$ 1989;8:848-51.

22 Word BM, Klein JO. Therapy of bacterial sepsis and meningitis in infants and children: 1989 poll of directors of programs in pediatric infectious diseases. Pediatr Infect Dis $\mathcal{F}$ 1989;8:635-7.

23 Mertsola J, Ramilo O, Mustafa MM, et al. Release of endotoxin after antibiotic treatment of Gramnegative bacterial meningitis. Pediatr Infect Dis $\mathcal{Y}$ 1989;8:904-6. 